\title{
The Implementation of Problem-Based Learning on Elementary School Students of Sukoharjo
}

\author{
M Suswandari ${ }^{1}$, Siswandari ${ }^{2}$, Sunardi ${ }^{3}$, and Gunarhadi ${ }^{4}$ \\ 1,2,3,4 Universitas Sebelas Maret Surakarta \\ \{1meidawatisuswandari@student.uns.ac.id, 22siswandari@staff.uns.ac.id, 3nardi_ip@uns.ac.id, \\ ${ }^{4}$ gunarhadi@fkip.uns.ac.id\}
}

\begin{abstract}
This research aimed to describe the implementation of the problembased learning model in elementary school students of Sukoharjo. The research method was qualitative research. The data were collected using observation, interview and documentation. The data were analysed using interactive data analysis. The research results describe that the teacher has not applied the problem-based learning model to the elementary school students of Sukoharjo maximally. The learning was still teacher-centred. Only certain students were active, which resulted in the gap in the learning process among the students. Students did not work together well in groups and they looked bored in learning.
\end{abstract}

Keywords: Learning Model, Problem Based Learning

\section{INTRODUCTION}

Nowadays, the applied learning method is generally teacher-centred. It is seen from the learning process which is dominated by lectures, question and answer, and interspersed with discussions on each material delivery. However, the existence of this learning method is not always bad even though it is dominated by conventional learning. Therefore, there should be variations in the classroom teaching and learning process by the teacher. One of the variations is in the learning model. The learning model has important factors in determining student learning activeness. The selection of learning models can also determine the quality of learning.

One of the learning models that determine the quality of learning is the problem-based learning model. Problem-based learning is a learning model that presents contextual problems so as to provide a stimulus for students to learn. Classroom learning that applies problembased learning makes students work in a team to solve real world problems. Therefore, they have problem solving skills [1].

Problem Based Learning (PBL) is learning that provides opportunities for students to express ideas explicitly, giving experiences that relate to ideas that students already have. The students' task is to distinguish and combine ideas about challenging phenomena. This PBL model encourages students to think creatively and imaginatively, reflect about models and theories, introduce ideas at the right time, try new ideas, and gain self-confidence [2]-[4].

Dasna further concluded that learning with the PBL model starts from problems (problems raised by students or teachers). Then, the students deepen their knowledge of what they already know and what they need to know to solve the problem. Students can choose problems they consider interesting to solve, so they are encouraged to play an active role in learning [5]. 
A finding describes that PBL model is more effectively used in learning applied to students compared to traditional methods (lecture methods and methods without involving the students' activeness and creativity in obtaining teaching materials). PBL model makes students active in learning and requires students to be able to solve problems made by the teacher or problems created by the learners themselves. Such activities will improve the students' achievement and learning outcomes effectively [5].

Problem-based learning improves the students' success due to the support from the curriculum. Problem-based learning is one component of the learning model in the 2013 curriculum. 2013 Curriculum is a new curriculum implemented in stages in educational units starting in the new academic year of 2013/2014. After one year in stages, the new curriculum has been carried out simultaneously in all education units starting in the new academic year of 2014/2015 (PERMEN K13). The 2013 curriculum is a continuation and refinement of the competency-based curriculum (KBK) and school-based curriculum (KTSP). The learning approach in the 2013 curriculum is scientific [6].

The scientific approach is regulated in Permendikbud No. 65 of 2013 concerning Primary and Secondary Education Process Standards. Scientific learning is learning that adopts scientific steps in building knowledge through the scientific method. The learning process involves three domains, namely attitudes, knowledge and skills. In scientific learning, the attitude domain includes substantial or teaching material transformation so that students "know why". The skill domain includes substances or teaching materials so that students "know how". The knowledge domain includes the substantial or teaching material transformation so that the students "know what" [7].

The scientific approach is the approach in the 2013 curriculum. The scientific approach is learning that encourages students to carry out scientific skills to actively observe, ask, reason, associate and communicate. The scientific approach is believed to be the golden mark of the knowledge, attitude and skill development [8]-[10].

Based on the preliminary observation result on the implementation of problem-based learning to the elementary school students of Sukoharjo, it was found that: (1) learning was still teacher-centred; (2) most students were passive in following the learning process and only $40 \%$ of them were active learning; and (3) the problem-based learning model has been implemented but not maximally yet. Therefore, this research aimed to describe the implementation of the problem-based learning model for the elementary school students of Sukoharjo.

\section{RESEARCH METHOD}

The type of this research is qualitative research. This qualitative research aimed to understand the phenomenon of implementing problem-based learning in the elementary schools in Sukoharjo. This qualitative research also explored the behavioural meanings beyond human actions. The meaning interpretation of this behaviour cannot be explored through theory verification as an empirical generalization, as is done in quantitative research. Data collection techniques in this research were observation, interviews, and document analyses in the form of books, worksheets, syllabus and lesson plans to describe the implementation of scientific learning with problem-based learning model. Observation is a process carried out by the researcher directly to observe the students' behaviours and activities in the class. The questions used in the interviews were open-ended given by the researcher to the participants. Therefore, the participants can channel their experiences as well as possible without being limited by the researcher's perspective or the findings of the previous 
researcher. The open-ended response to the question allows the participants to create options to respond. In addition to observations and interviews, the researcher also collected the data through documentation to deepen the data presented by the elementary school students in Sukoharjo. The data analysis technique in this qualitative research was interactive analysis, which includes data reduction, data display, and conclusion and data verification.

\section{RESULT AND DISCUSSION}

The learning model conducted at Sukoharjo elementary schools in adjusting the scientific approach with the 2013 curriculum, which is problem-based learning (PBL) model. The application of this model will be able to help teachers to relate learning materials to students' real-world conditions. In addition, PBL model encourages students to conduct investigations and communicate their findings to actively build their own knowledge in classroom learning.

The information obtained from the observation result carried out in the 2018/2019 academic year in Sukoharjo elementary schools is that problem-based learning model was rarely applied in scientific learning. Classroom learning using the problem-based learning model is quite successful in changing the students' way of thinking to solve problems encountered in learning. This is evident since the implementation of the problem-based learning model, in which all students were accustomed to being able to organize their groups, respect their friends in discussion, form an organizational structure so that all the students could be responsible with their work, solve problems, ask and answer questions given by their teachers and friends. This learning model makes students able to know how they to learn to respect others, aroused their learning spirit, makes class atmosphere to be alive and fun, makes teachers only as student facilitators by orienting students to problems, organizes the students to learn, provides individual/group experiences, develops and presents the work, analyses and evaluates the problem solving process.

The researcher provided observation sheets for the teachers conducting the research and for the students. The observation sheet also has three learning steps; they are pre-activity, main activity and post-activity. The activities are in accordance with the learning model syntaxes. The preliminary activity is a preparatory activity consisting of praying, attendance checking, and classroom readiness, and physical and mental readiness of the students. Besides, in the problem orientation of the pre-activity in problem-based, the students were given apperception to raise the students' spirit in learning. Then, the teacher conveyed the learning objectives to be achieved. Next was the main activity. In the main activity, there are 3 syntaxes to be done, student organization, investigation guidance and developing and collecting data. In the student organization syntax, the teacher provided the students with an experiment in the hope that they could explain what they have seen. In addition, the teacher guided them by monitoring their experiments.

The next syntax was investigation guidance. In this syntax, they students did group works, in which the group was randomly and evenly chosen. The fourth syntax was developing and collecting data. The students did the tasks according to what they got. Then, the teacher guided the students in writing, doing the task and discussing with their friends. The last syntax was presenting and evaluating. This syntax includes in the post-activity of learning. The students and teacher summarized the learning that has been done. From this can be seen that learning activities will influence the students' thinking for the future life. From the implementation of teaching observations above, it can be said that the teacher has carried out the teaching-learning process well in accordance with the model syntaxes used. 
The PBL material delivered is not only the material delivered by the teacher, but also that of the presentation stage, including: The teacher created groups of 5 students and asked the students to open a thematic textbook. The teacher gave a problem that exists in the sub-theme. Meanwhile, the students discussed with their group friends while the teacher watched them. The teacher's tasks were asking and approaching each group in case that there found difficulties in solving problems. The teacher encouraged the students to search for and gather appropriate information, explored the experiences of each student, and then the students transferred their knowledge with each other to solve the problem. The teacher helped the students who found difficulties. The representative from each group presented in front of the class while the other groups paid attention and asked questions or gave additional opinions after the presentation. Afterwards, the teacher evaluated the material.

However, during the observations conducted on the elementary school students in Sukoharjo, the researcher found that the students' enthusiasm and interest were still low. This is because only active students were willing to contribute ideas in discussions. Based on the interview result, the factors that led to low interest in learning are: (1) One student did not understand the material because of lack of attention to the material so that it is difficult to understand learning; (2) Presentations in front of the class still rely on bright students and average female students; (3) A conducive and pleasant climate in the problem-based learning model was not created well because only active and intelligent students had the awareness to contribute ideas in discussions; (4) There were still many students who often talked about the topic out of the context of learning rather than discussed with their groups; (5) Some students had difficulty focusing on the material discussed; (6) There were still many students who had difficulty in the problem solving process. They began to get used to the problem solving process even though there were still some students who often talked about the topic out the context of learning rather than discussed with the group.

In addition, based on the observation of the classroom learning process, it was found that: (1) Only a few students participated to solve the problem. Only 1-2 students in a group actively contributed ideas; (2) Some students were individualistic; They were more comfortable searching for sources and materials by themselves rather than sharing and discussing with their group friends; (3) There was no question and answer process among the students when group presentations took place; (4) Some smart students were often relied on by their friends to complete the discussion on the whole material; (5) There were still some groups whose discussion looked awkward because there was no interaction among the students in the discussion group.

Problem-based learning that took place in the classroom was done naturally in the form of students activities to work and experience, find and discuss problems, and find problem solving, not transfer of knowledge from the teacher to the students. The students understood the meaning and benefits of learning, their status, and how to achieve them. They realized that what they were learning was useful for their future lives. The students were accustomed to solving problems, finding something that works for themselves and struggling with ideas [11].

PBL is a problem based learning model that uses real world contexts. Real-life problems mean problems that can be imagined by students. Problem based learning was chosen because of several advantages such as providing problems close to real life, giving students the opportunity to make a choice of solutions to a problem, motivating them to be actively involved in learning activities, and encouraging them to learn in collaborative settings [12].

On the other hand, the scientific approach is also highly recommended in the 2013 curriculum as contained in the Permendikbud standard process No.22 of 2016 [7] that the scientific approach steps are 5M namely observing, asking, gathering information, reasoning 
and communicating. Scientific approach is a learning process designed in such a way that students actively construct concepts, laws or principles through stages of observing (identifying or finding problems), formulating problems, proposing or formulating hypotheses, collecting data, drawing conclusions and communicating concepts, laws or principle found [7].

In addition, the other research conducted by Powner (2006) stated that the students taught with the scientific approach generally have intuition in understanding how to conduct investigations and evaluate the opinions they have conveyed. Both scientific approach and PBL model use a problem in learning. In PBL approach, the learning starting point is a real problem while the starting point of the scientific approach is the problem as the result of the students' thinking process. Therefore, through a combination of the two learning models, it is believed that it can produce a learning process that involves students in full in solving problems [13].

Therefore, students who have been taught with conventional learning models indeed often feel bored with the model delivered. Eventually, it changes to regular learning because they focus on problems and their motivation increases [14]. This is a thinking process that is trained in PBL's second syntax. Students conduct investigations in groups as demands in the third syntax. This PBL prepares students to think critically, analytically, and find using various sources. During investigation, students practice thinking scientifically according to the investigation procedure [13].

\section{CONCLUSIONS}

To improve the quality of student learning, a teacher must be able to plan the right learning model by using the help of learning media to make the students more interested and enthusiastic in receiving all the materials delivered. The selection of learning models suitable with the curriculum objectives and students' potential is the ability and basic skill that teachers must possess. The role of the teacher in learning activities is as a facilitator and motivator. The teacher provides facilities for students to be able to reconstruct the abilities they already have. In addition, teachers must also be able to motivate them to always actively improve their achievements. The problem-based learning model is part of the learning model in the scientific approach in the 2013 curriculum. The research results describe that the teacher has not applied the problem-based learning model to the elementary school students of Sukoharjo maximally. The learning was still teacher-centred. Only certain students were active, which resulted in the gap in the learning process among the students. Students did not work together well in groups and they looked bored in learning.

\section{ACKNOWLEDGMENT}

The author expressed his gratitude to LPDP who has helped with this research fee.

\section{REFERENCES}

[1] A. Treesirichod, L. Phivthong-ngam, A. Sangpanich, S. Chansakulporn, and C. Kusumaphanyo, "The Attitudes of Medical Students towards Problem-Based Learning during the Clinical Years," South-East Asian J. Med. Educ., vol. 12, no. 1, p. 41, 2018.

[2] S. Mumtaz and R. Latif, "Learning through debate during problem-based learning: an 
active learning strategy," Adv. Physiol. Educ., vol. 41, no. 3, pp. 390-394, 2017.

[3] S. Amamou and L. Cheniti-Belcadhi, "Tutoring in Project-Based Learning," Procedia Comput. Sci., vol. 126, pp. 176-185, 2018.

[4] Z. Zhang, "Research on Curriculum Reform of Career Planning and Employment Guidance Based on PBL Teaching Method," vol. 252, no. Jahp, pp. 838-841, 2018.

[5] E. Appella et al., "A Decaepitope Polypeptide Primes for Multiple CD8+ IFN- and Th Lymphocyte Responses: Evaluation of Multiepitope Polypeptides as a Mode for Vaccine Delivery,” J. Immunol., vol. 168, no. 12, pp. 6189-6198, 2014.

[6] F. Fischer, I. Kollar, S. Ufer, B. Sodian, and H. Hussmann, "Scientific Reasoning and Argumentation : Advancing an Interdisciplinary Research Agenda in Education," Front. Learn. Res., vol. 5, no. July, pp. 28-45, 2014.

[7] M. Pendidikan, D. A. N. Kebudayaan, and R. Indonesia, "No Title," 2016.

[8] J. R. Helliwell, " The Scientific Method: Reflections from a Practitioner . By Massimiliano di Ventra. Oxford University Press, 2018. Pp. 128. Price GBP 13.99. ISBN 9780198825623. ," J. Appl. Crystallogr., vol. 51, no. 5, pp. 1509-1510, 2018.

[9] E. Castellani, "Scientific Methodology: A View from Early String Theory," no. January, pp. 1-14, 2018.

[10] P. Aránguiz, A. Opazo, F. Orozco, Á. Suazo, V. González, and E. Forcael, “Application of Problem-Based Learning to Teaching the Critical Path Method," J. Prof. Issues Eng. Educ. Pract., vol. 141, no. 3, p. 04014016, 2014.

[11] Sri Sukaptiyah, "PENINGKATAN HASIL BELAJAR PKn MELALUI MODEL,” pp. 114-121, 2015.

[12] S. Fukuzawa, C. Boyd, and J. Cahn, "Student Motivation in Response to Problem-based Learning," Collect. Essays Learn. Teach., vol. 10, p. 175, 2017.

[13] L. D. Pratama, W. Lestari, and J. Jailani, "Implementasi Pendekatan Saintifik Melalui Problem Based Learning Terhadap Minat dan Prestasi Belajar Matematika," JMPM J. Mat. dan Pendidik. Mat., vol. 3, no. 1, p. 11, 2018.

[14] K. Saddhono and M. Rohmadi, "A Sociolinguistics Study on the Use of the Javanese Language in the Learning Process in Primary Schools in Surakarta, Central Java, Indonesia." Int. Edu. Stu., vol. 7 no.6 pp 25-30, 2014 